\title{
The puerperium in dairy cows: ovarian activity, uterine involution and follicular dynamics
}

\author{
Puerpério em vacas leiteiras: atividade ovariana, \\ involução uterina e dinâmica folicular
}

José Carlos dos Santos Breda ${ }^{[a]}$, Luiz Ernandes Kozicki[b]

[a] Veterinarian, MSc in Animal Science, Professor Instituto Federal de Educação, Ciência e Tecnologia Catarinense (IFC), Araquari, SC - Brazil, e-mail: jose.breda@ifc-araquari.edu.br

[b] Veterinarian, Doctor in Veterinary Medicine, Professor Pontifical Catholic University of Paraná (PUCPR), São José dos

Pinhais, PR - Brazil, e-mail: kozicki.l@pucpr.br

\begin{abstract}
The study of ovarian follicular dynamics (OFD) and other changes in the bovine reproductive tract has developed significantly over the past two decades, primarily due to the use of non-invasive investigative approaches such as ultrasound. Advances in ultrasound examinations have provided a better understanding of ovarian activity, uterine involution, oviducts status, and other segments of the reproductive tract in the bovine postpartum period. Procedures including tracking of the reproductive tract have likewise aided in the development of new methodologies and techniques to improve reproductive performance in cattle. The aim of this review was to summarize knowledge regarding the reproductive tract in dairy cows during the postpartum period.
\end{abstract}

Keywords: Ovarian activity. Anestrus. Follicular dynamic. Dairy cows. Puerperium.

Resumo

O estudo da dinâmica folicular ovariana (DFO) e outras alterações no aparelho reprodutor bovino tem progredido significativamente ao longo das últimas duas décadas, principalmente devido a utilização de abordagens de investigação não-invasiva como a ultrassonografia. Avanços em exames ultrassonográficos proporcionaram uma melhor compreensão da atividade ovariana, involução uterina, status dos ovidutos e outros segmentos do trato reprodutivo em bovino no período pós-parto. Procedimentos, incluindo o rastreamento do trato reprodutivo têm, da mesma forma, ajudado no desenvolvimento de novas metodologias e técnicas para melhorar o desempenho reprodutivo em bovinos. $O$ objetivo desta revisão foi resumir conhecimentos a respeito do trato reprodutivo em vacas leiteiras durante o período pós-parto.

Palavras-chave: Atividade ovariana. Anestro. Dinâmica follicular. Vacas leiteiras. Puerpério. 


\section{Introduction}

Animal efficiency is considered one of the most important aspects related to profitability in the livestock industry, as it directly affects herd productivity, and depends primarily on nutrition, health, genetics, and management factors. The bovine female may be affected by metabolic or physiological disorders that cause infertility. Similarly, there is a need to adopt and implement preventive and therapeutic practices that are dependent on routine and systematic gynecological control.

The postpartum period, also called the puerperium, is a physiological and global process of modifications occurring in the female reproductive tract after parturition that leads to recovery from the changes that took place during pregnancy. Consequently, six weeks after parturition, the bovine reproductive tract achieves the volume, size, position, and reproductive capacity required for the next pregnancy (Grunert and Birgel, 1998).

According to Opsomer at al. (2000), a normal ovarian cycle in the puerperium is one of the most important reproductive events related to high production in modern dairy cattle herds, which is aimed at achieving maximum potential after parturition. However, the slow return of reproductive function during the puerperium period in dairy cows is a major limitation that affects the success of subsequent reproductive management programs, such as artificial insemination (AI), and marks the beginning of the voluntary waiting period (VWP). The occurrence of early and frequent estrus after parturition is associated with increased reproductive performance due to a consequent restoration of the uterine environment (Thatcher and Wilcox, 1973; Thatcher et al., 2006).

Factors related to nutrition, including kind, quantity, and intake capacity (Domínguez, 1995; Zain et al., 1995; Laven et al., 2004; Roche, 2006; Artunduaga et al., 2008; Castaneda-Gutiérrez et al., 2009), as well as body condition score (BCS), energy, and metabolism (Zurek et al., 1995; Kendrick et al., 1999; Butler, 2000) can positively or negatively influence follicular development and ovulation in the early puerperium. General or local uterine disorders also cause delays in ovarian activity (Sheldon, 2002a; Mateus et al., 2003; Peter, 2004;
Sheldon, 2004; Sheldon and Dobson, 2004; Foldi et al., 2006; Azawi, 2008), and can consequently hinder subsequent reproductive events.

The aim of this review was to present viewpoints related to follicular dynamic in dairy cows, and to highlight the influence of follicular dynamics on the reproductive performance of dairy cattle during the puerperium period.

\section{Follicular dynamic of the ovaries in the puerperium of dairy cows}

According to Sá Filho et al. (2014), knowledge of follicular dynamics allows for the efficient control of reproduction and other related procedures such the manipulation of the estrous cycle and the induction of postpartum estrus, and promotes the more effective use of reproductive biotechnologies. The ovaries function as units, and primarily influence follicular development through the endocrine pathways that involve ovarian and uterine endocrine secretions, as well as gonadotropins and their receptors. The dominant and subordinate follicles act throughout the stages of recruitment, growth, and stasis, as well as during regression, as determined by distinct morphological and biochemical characteristics (Adams et al., 2008).

Several previous reports have stated that knowledge of follicular dynamics and the physiology of the corpus luteum (CL) increased reproductive performance, applying hormones and others related drugs (Macmillan and Thatcher 1991; Figueiredo et al., 1997; Aerts and Bols 2010; Cummins et al., 2012; Sales et al., 2012; Uslenghi et al., 2014) for AI, induction and synchronization of oestrus, ovarian superovulation, and embryo transfer, among others.

In cows, almost all of the ovarian follicles undergo atresia, and around 60 days are required to activate the primordial follicle to reach ovulatory size (Vasconcelos, 2000). During this time, a standard follicular wave follows (Ireland et al., 2000; Lucy, 2000; Ginther et al., 1996) that stimulates several stages of follicular growth and atresia, based on subsequent oocyte maturation or degeneration (Viana et al., 2010; Cerri et al., 2011). Throughout puberty, a large number of primordial follicles are recruited from the follicular reserve population that develop into ovulatory follicles, and are released 
as oocytes with the potential for fertilization (Kornmatitsuk et al., 2009). Consequently, the number of primordial follicles present in ovaries is correlated with the number of pre-ovulatory follicles that will reach maturity (Fortune et al., 2013).

The number of follicular waves varies among animals of the same breed, and even in an individual animal, and can occur once, twice, or three or four times (Figueiredo et al., 1997; Gambini et al., 1998; Bo et al., 2000; Cummins et al., 2012). Such variations can occur due to factors including nutrition, management, milk yield, lactation period, and early postpartum period (Ginther et al., 1996). The first follicular wave emerges during ovulation on day $0(\mathrm{~d} 0)$. The emergence of the second wave occurs on days 9 and 10 (in cases of two wave cycles), or on days 8 or 9 (in three wave cycles). By the third wave, the follicular wave emerges on day 15 or 16 . The dominant follicles, under the influence of progesterone (P4; diestrus), undergo atresia. The dominant follicle (DF) present at luteolysis becomes the ovulatory follicle, and the emergence of the next wave is delayed. By the second wave cycle, the CL begins to regress on day 16 , and by the third wave cycle, the CL regresses by day 19 , which results in 19-20 or 22-23 day estrous cycles, respectively (Adams et al., 2008). In addition, an increase in the proportion of three wave cycles has been associated with poor nutrition and heat stress (Bo et al., 2003).

The theory of follicular waves was first described by Rajakoski (1960), who demonstrated the existence of two waves of bovine antral follicular development, and the resulting production of pre-ovulatory follicles in each wave. Further, the existence of follicular waves was confirmed in slaughterhouse animals many years before the development of the ultrasound machine. Other studies were subsequently reported, but the data was discrepant following the use of ultrasound, when changes in the ovaries could be tracked with greater accuracy.

The primordial follicle reserve isformed during fetal development, or immediately after birth. The resulting oocytes remain latent in prophase I of meiosis (Tabatabaei et al., 2011). This break oocyte development persists for a variable length of time from follicle to follicle (Hafez, 1995). The mechanisms responsible for triggering follicular growth (activation of the primordial follicles) as well as the mechanism that determines variation in the period of time to the beginning of growth remain unknown (Casasola et al., 2014). The reserve of primordial follicles could be used to decide specific issues related to infertility, to create new contraceptive methods, or to delay menopause in women. However, this will be possible only after the factors responsible for the extension of follicular growth from the primordial stage to ovulation are elucidated (Adams et al., 2012; Stubbs et al., 2013).

According to Driancourt (2001), follicular recruitment (the start of folliculogenesis dependent on gonadotropins contained in the pre-ovulatory follicle) occurs during a "window of recruitment," which lasts for two days in cattle, and only gonadotropin dependent follicles are recruited. In cattle, five to 10 follicles (on average) are recruited by wave, and all are potentially capable of being discharged during ovulation as an oocyte (Gibbons et al., 1997).

The follicles are continuously recruited, with the variation in intensity dependent on the stage of follicular development and the estrous cycle. The increase in the mitotic rate of the follicular epithelium cells, as well as the development of the antrum, is more hasted at the end of the estrous cycle. The "chosen follicle" is selected to progress to ovulation according to maturity state and the onset of pre-ovulatory gonadotropin (Adams, 1999).

In cattle, the emergence of the follicular wave is characterized by two or three days of growth, and the presence of 8 to 41 small follicles (three to four $\mathrm{mm}$ diameter) that are detected by ultrasound (Adams and Pierson, 1995; Utt et al., 2003; Figueiredo, 1995). These waves provide to find a small, medium, and large follicle population in each ovary during all days of the estrous cycle (Santos and Vasconcelos, 2007). A significant number of reports have characterized these wave patterns in the estrous cycle in European cattle breeds (Bos taurus). Borges et al. (2001), Viana et al. (2010), and Chasombat et al. (2013) reported similar types of wave patterns for Holstein-Zebu crossbred heifers and zebu cows (Bos taurus indicus). Further, the data was confirmed by studies conducted by Zeitoun et al. (1996) and D'enjoy et al. (2012) that evaluated follicular dynamics in Brahman cows (Bos taurus indicus). The rate of follicular growth was similar for 
all follicles in the wave for approximately two days, until one was selected to continue development to a DF, while the others became atretic and regressed (subordinate follicles). This reports suggested that the DF suppressed the growth of the subordinate follicles in the same wave, as well as emergence in the subsequent follicular wave by blocking recruitment (Ko et al., 1991; Adams and Pearson, 1995). Further, the magnitude of dominance was usually defined by the size difference between the DF and the subordinate follicles (Driancourt, 2001).

During the stages of follicular growth and atresia, a reorganization of the blood capillaries occurs to provide the tissues with the required blood supply. The process is called angiogenesis, and is dependent on the production of specific angiogenic factors (Barboni et al., 2000). Although the mechanisms involved in follicular development are not completely clarified, it is known that the gonadotropins have a relevant function. The regulation of ovarian vasculature may be involved in these mechanisms, and may improve the blood supply to the follicle and consequently, the contact of the gonadotropins and other factors with the follicular cells. Research conducted in rodents, primates, and buffalos has indicated that both in vitro and in vivo, vascular endothelial growth factor-(VEGF) was the main angiogenic factor in the ovarian vascularization, and that production was influenced by gonadotropins (Fatima et al., 2013).

In cattle, the appearance of LH receptors in granulosa cells is a pre-requisite for the establishment of dominance and ovulation after the LH peak (Ireland and Roche, 1983, Simões et al., 2012). Another contributing factor was the reduction in IGF binding proteins like including IGFBP2 and IGFBP4 (De la Sotta et al., 1996; Mihm et al., 1997; Satchel et al., 2013). Follicular dominance be enhanced by IGF-1 and the VEGF. According to Chase et al. (1998), a growth hormone (GH) deficiency in cattle will limit the production of IGF-1, and may impair follicular dominance. This indicated that the induction of LH receptors might be partially mediated by IGF-1. Reports have shown that LH stimulates the production of VEGF, a potent stimulator of angiogenesis, and that IGF1 may enhance the action of LH during angiogenesis (Zeleznik et al., 1981; Pretheeban et al., 2010; Satchel et al., 2013).
The emergence of a follicular wave is preceded by an increase in plasma follicle stimulating hormone (FSH) concentrations. The main effects of FSH are to induce aromatase activity in granulosa cells so that they gain the ability to produce estradiol, to stimulate the production of inhibin and follistatin (Singh and Adams, 1998; Takedomi et al., 2005), and to suppress the release of FSH by inhibiting the emergence of new waves (Singh et al., 1999; Takedomi et al., 2005). At the end of a dominance period (ovulation or static phase in an anovulatory DF), circulating FSH levels begin to rise within two days, and the peak is expected approximately 1224 hours after the emergence wave (Bergfelt et al., 1994).

The pulse frequency and amplitude of LH are influenced by circulating concentrations of P4 and estradiol. High levels of P4 produced by a functional CL in diestrus or pregnancy suppresses the pulsatile frequency of LH. The DFs grow, and become dominant for a long period when the $\mathrm{LH}$ pulse frequency is high. An increase in estradiol concentrations following a decrease in $\mathrm{P} 4$ due the luteolysis increased the frequency of LH pulses, concurrent with the appearance of a large preovulatory follicle (Adams et al., 2008; Aerts and Bols, 2010). LH has little influence on the control of follicular recruitment, since recruitment occurs when the frequency of LH pulses was reduced (Murphy et al., 1991; Evans et al., 1994; Aerts and Bols, 2010).

The consensus was that $\mathrm{LH}$ is involved in late DF growth, while the remaining follicles are subject to the atresia process. Sirois and Fortune (1990) and Fortune (1993) demonstrated that the regression of the CL in cows treated with a slow release P4 device was associated with an increase in $\mathrm{LH}$ pulsatility and length of the dominance phase. Duffy et al. (2000) found that injections of exogenous LH resulted in an increase in the DF diameter. LH plays a key role in the development of follicles larger than $8 \mathrm{~mm}$. The main effect of LH was the stimulation of androgen production by theca cells. Inhibin, which is produced in large quantities by granulosa cells, may also stimulate androgen production via paracrine way (Mazerbourg et al., 1999). This increases the bioavailability of IGF-1 and IGF-2 at the level of granulosa and theca cells, respectively. In the granulosa cells, the IGFs increase sensitivity to 
LH (Driancourt, 2001), and consequently maximize sensitivity to ovulation.

As previously reported, circulating concentrations of $\mathrm{P} 4$ and estradiol exert influence on the pulse frequency and amplitude of LH. When the total plasma concentrations of $\mathrm{P} 4$ reached 1.7 $\mathrm{ng} / \mathrm{ml}$, six LH pulses at an amplitude of $0.2 \mathrm{ng} /$ $\mathrm{ml}$ per eight hours were observed. Conversely, 1.8 pulses every eight hours at an amplitude of 0.34 $\mathrm{ng} / \mathrm{ml}$ were observed when the concentration of P4 was $5 \mathrm{ng} / \mathrm{ml}$ (Jaiswal, 2007). Further, an increase in the concentration of estradiol at reduced P4 concentrations after luteolysis increased the frequency of LH pulses, and resulted in the appearance of a pre-ovulatory follicle (Aerts and Bols, 2010).

After the ovulation, the luteinization of the corpus hemorraghicum ensues, which causes the DF to rupture and the formation of a $\mathrm{CL}$, which produces P4 (Skarzynski et al., 2013). The morphology of the CL and plasma progesterone concentrations are good indicators of its synthesis. Intense angiogenesis, proliferation of granulosa and theca cells from the follicular wall after ovulation, and differentiation (luteinization) during the first five to six days after ovulation results in a progressive increase in plasma $\mathrm{P} 4$ concentrations from $<1 \mathrm{ng} /$ $\mathrm{ml}$ three days after ovulation to approximately 3 $\mathrm{ng} / \mathrm{ml}$ six days following ovulation. The peak in plasma P4 levels occurs between 10 and 14 days post-ovulation ( $>4 \mathrm{ng} / \mathrm{ml}$ ). However, a decline occurs after the 16th day due to induced release of prostaglandin F2a in the endometrium (Singh et al., 2003), which promotes luteolysis.

\section{Ovarian activity during the puerperium}

During the puerperium period, the uterus involutes, and the hypothalamic-pituitary-ovarian axis releases cyclical secretions of gonadotropic and gonadal hormones, which results in the first postpartum ovulation and regular estrous cycle. In the physiological puerperium, these events are completed six weeks after delivery (Peter et al., 2009). Further, ninety percent of cows will have the first postpartum ovulation in this period (Peter and Bosu, 1988). However, the three-week or greater interval between parturition and ovulation can be delayed in dairy cows (Opsomer et al., 1998). The reproductive organs return to normal physiological and anatomical pre-pregnancy status, and the major events involved in the functioning of the postpartum hypothalamic-pituitary-ovarian axis are delayed due to the redistribution of energy for milk production (Aguilar et al., 2004).

Clinical and subclinical infections in the puerperium affect ovarian activity (Azawi, 2008). Uterine diseases suppress the release of GnRH and LH and their localized effects, which in turn decreased folliculogenesis (Mateus et al., 2002). The ensuing mechanisms triggered by the negative effects of uterine infection may involve an inflammatory response (Sheldon and Dobson, 2004; Williams et al., 2007), changes in the uterine bacterial flora (Elkjær et al., 2013), or changes in the uterus that might decrease blood flow in the uterus (Heppelmann et al., 2013; Mateus et al., 2002). Cows that experience an abnormal puerperium will be affected by a delay in uterine involution and the surge in ovarian activity may be impaired (Kozicki, 1982). High circulating concentrations of prostaglandin F2a (PGF2a) and serum albumin in the first three weeks after parturition (a common outcome of subclinical infections) act as a uterine signal, and prevent the early onset of ovarian activity (Peter e Bosu, 1988; Peter et al., 1990; Sheldon et al., 2002b; Krause et al., 2014; Gabler et al., 2009).

The suppression of ovarian activity in the early postpartum period may improve uterine involution in cows with or without uterine disease (Heppelmann et al., 2013). According Silvestre et al. (2009), treatment with deslorelin (5 mg) during the postpartum period suppressed ovarian follicular development by stimulating uterine and cervical involution, increased the tonus of the uterine wall, decreased the frequency of purulent cervical discharge, and reduced inflammation in the reproductive tract. These reports highlight some topics related to the advantage of full ovarian activity in the early puerperium that require further discussion.

In the puerperium period, nutritional requirements increase rapidly due to milk production. Consequently, cows may be affected by a negative energy balance (NEB) and/or disproportionate energy metabolism (e.g. fatty liver, ketosis, acute and sub-acute ruminal acidosis), 
diseases related to mineral imbalance (e.g. milk fever, clinical and subclinical hypocalcemia), or immune function disorders (e.g. retained placenta, mastitis, and metritis).

At the end of pregnancy and early lactation, dairy cows present a period of NEB, which occurs, among other factors, because the peak milk yield is established 4 to 6 weeks before the dry matter intake (DMI) peak. This fact may extend for 10 to 12 weeks postpartum, since the energy used to maintain milk production is greater than the energy acquired by feeding (Sartori and Mollo, 2007; Schneider et al., 2014). Delayed postpartum ovulation is directly related to the energy status of the cow (Schneider et al., 2014), i.e. the higher the NEB, the greater will be the interval to the first ovulation. In NEB period, there is a loss of body condition score (BCS) in cows, growing with the decrease in food intake. This BCS fall (often independent of body condition the cow present to delivery), is directly associated with delayed first ovulation and increase the days open. Cows under greater loss of BCS in the first weeks of lactation showed poorer reproductive efficiency (Butler and Smith, 1989; Ferguson, 1991), included cows that calved with high BCS (Zulu et al., 2002). The mechanism by which the NEB and loss of BCS have a relation to the delay of postpartum ovulation is probably associated with low LH pulsatility (Butler and Smith, 1989). The restart of normal LH pulsatility is the determining factor for resumption of follicular growth and cyclicality in postpartum cows (Schneider et al., 2014). It was demonstrated that a reduced availability of glucose and insulin was related with a lower frequency of LH pulses and low IGF-I in the liver, which reduce the response of the ovaries to gonadotropin.

Dehydration is also associated with NEB events and the reduction of rawintake (Esposito etal., 2014). Dairy cows are highly susceptible to oxidative stress associated with metabolic adaptation processes in early lactation that increase the production of reactive-oxygen species such as melondialdeid, and cause a reduction in serum glucose (Turk et al., 2008). Cows affected by NEB can head nutrients from the reproduction limiting the number of ovarian growth and maximum size delaying the first ovulation, hindering estrus expression and decreasing plasma P4 concentrations from the DF. Further, ovulation is delayed by inhibition of the $\mathrm{LH}$ pulse frequency and suppression of blood glucose, insulin, and IGF-1, which reduces the production of estrogen by the DF (Leroy et al., 2008).

Conversely, increased food intake can suppress reproduction due to steroid metabolism. The increased food intake enhances hepatic perfusion, which increases the metabolism of estradiol and P4 (Sangsritavong et al., 2002), and contributes to anovulation (Walsh et al., 2007), the release of an enlarged DF (Sartori et al., 2004.), multiple ovulation (Lopez et al., 2005.), or poor luteal function (VillaGodoy et al., 1988.) and delayed luteal regression (Opsomer et al., 2000; Petersson et al., 2006). These events are most likely caused by the development of a DF to a no estrogen-sensible, resulting on in inadequate endometrial PGF $2 \alpha$ production of endometrial PGF2 $\alpha$ (Sangsritavong et al., 2002; Sartori et al., 2004).

Hepatic function also influences the reproductive performance of cows in the puerperium period. According to Bertoni et al. (2008), cows with low or intermediate hepatic activity exhibited a greater number of days open (139 versus 93, respectively), a greater number of services per pregnancy (2.68 versus 1.65 , respectively), and lower milk production (38.3 versus $40.8 \mathrm{~kg} /$ day, respectively) compared to cows with a high rate of hepatic activity. Animals with a low rate of hepatic activity (bilirubin and blood urea) also had a higher number of inflammatory conditions in the first month of lactation and more severe NEB, and exhibited lower milk production and fertility than cows with high hepatic activity. High dietary protein levels (16$17 \%$ ) can likewise be detrimental to reproductive performance due to high concentrations of urea (Tamminga, 2006). According to Oliveira Filho et al. (2010), proper nutritional supplementation and good BCS during parturition help to maintain ovarian follicular function, favoring the follicular emergence. According to Silvestre et al. (2011), the supply of oils, rich in fatty acids, provide improved immunity, balanced NEB, and better postpartum reproductive rates.

\section{Ovarian activity during the puerperium}

Ultrasound examination (non-invasive, easy to operate and safe), became a widespread tool in 
veterinary medicine (Nepomuceno et al., 2013). In animal reproduction, it has become indispensable in the use of gynecological and andrologic evaluation, so as for several assisted reproductive biotechnologies. According Medan and Abd El-Aty (2010), ultrasound provides a detailed assessment, sometimes no perceptible by other methods for diagnosis structures. Ultrasound is widely used as additional tests on reproductive and obstetric evaluation, improving the diagnosis of ovarian disease, oviducts, and concept diseases, among others. Ultrasound examinations also provides the reproductive control of individuals or herds through early pregnancy diagnosis, detection of embryo viability, determining the number of fetuses, fetal sexing, and the monitoring of follicle and corpus luteum development in the different phases of the reproductive cycle (Amer, 2010).

According to Peixoto et al. (2010), the formation of the ultrasound image is based on the piezoelectric effect, mechanism in which is possible the transformation of energy into another one. By providing electrical pulses to the device, it creates an electric potential difference (voltage in crystals), which vibrates. These vibrations are transformed into mechanical /sound waves, which are addressed to the patient's body and undergo mitigation with the tissues (Drost, 2010). Mitigation is defined by sound waves propagating through a medium (Kealy and McAllister, 2005). In the reflective surfaces, the sound that returns back to the transducer is converted into electrical pulses and then presents itself as a form of light points on the display. Thus, the higher the amplitude of the returned sound, greater the intensity of the light point (Carvalho, 2004).

Ginther and Pierson (1984) performed the first ovarian ultrasound scans in cattle. Consequently, they observed the presence of two waves of follicular growth during the bovine estrous cycle. The ultrasound images were composed of twodimensional arrays that differed in their gray scale values (Pierson and Adams, 1995; Kremkau, 1998). Each pixel was described by one of 256 shades of gray $(0=$ black and $255=$ white $)$, and represented a discrete tissue reflector (Pierson and Adams, 1995). The ultrasound image of a tissue was referred to as echotexture, and was confirmed by the histological structure of the tissue (Singh et al., 1997). Computer algorithms designed specifically for the analysis of ultrasound images have since been developed to overcome inconsistencies in visual evaluations, and to provide a quantitative approach to the analysis of the gray-scale pixel values (Vassena et al., 2003).

These algorithms have been used extensively in studies that characterized the echotexture dynamics of ovarian structures for different stages of the follicular wave (Tom et al., 1998). Specific changes in the phases of DF, SF, and CL were characterized by images on the computer.

In vivo studies employing ultrasonography to evaluate follicular development and ovulation relative to the position of the CL or DF were not consistent with the local effect (Adams, 1999). Consistent changes in the ultrasound images have been associated with the physical and endocrine status of ovarian follicles (Singh et al., 1998).

Vassena et al. (2003) found that the average gray scale values of the antral DF were smaller than values from the subordinate follicles. The type of follicle (dominant or subordinate) on day 7 (d7) had mean gray scale values lower than the values on $\mathrm{d} 2, \mathrm{~d} 3$ or $\mathrm{d} 5$. As well, the interaction between the days of the wave and the type of follicle was not significant. The heterogeneity analysis revealed no influence from the day of the wave or from the follicle type. The authors also found a similar pattern in the gray scale values for the wall, peripheral antrum, and perifollicular stroma in the DF and SF. The values tended to follow a pattern in days five to seven, which was maintained in all follicular segments. The same authors found no local effects of the DF or CL on the echotexture of the subordinate follicles examined. Additionally, there was no local effect of the DF on the CL echotexture, except those involving the levels of gray scale in the antrum. Singh and Adams (2000) observed reduced thickness of the granulosa layer between the end of growth and the early static phase (d3) leading to the regression phase (d6). Vassena et al. (2003) described average gray scale values and decreasing gray scale levels from the onset of the static phase to the dominant follicle phase, as well as the regression to subordinate follicles. However, according to Singh et al. (1998), the average gray scale values of both follicles in the perifollicular stroma during the late static phase and the regression phase were higher than during the previous phase. Vassena et 
al. (2003) explained this apparent discrepancy by the difference in the perifollicular vascular flow and quality of the images.

The sonographic characterization of ovarian follicles and verification of oocyte competence was also performed by Vassena (2001). The results indicated that oocytes collected from $\mathrm{SF}$ on $\mathrm{d} 5$ of the follicular wave were more competent than oocytes collected from $\mathrm{d} 2, \mathrm{~d} 3$, or $\mathrm{d} 7 \mathrm{\text {ofthewave.The }}$ differences between the values of the DF and SF in all segments analyzed were lower on d5. Following the analysis of oocyte competence associated with follicular status, it was possible to analyze the ultrasound images to identify follicles that produced competent oocytes (Salamone et al., 1999).

Studies conducted using uterine ultrasonography in the puerperium period contributed valuable information to current knowledge of uterine events in this period. Using Doppler, Herzog and Bollwein (2007) reported a sharp decline in uterine blood flow during the postpartum period, especially in the first week after parturition. The average frequency and amplitude of myometrial contractions were described by Bajcsy et al. (2005), who reported a decrease in contractions during the early puerperium period in cows. After a significant peak in uterine contractions during the first post-treatment wave, the values of oxytocin and carbetocin groups remained high during the second hour, returned to baseline levels during the third hour, and reached physiological levels after 12 hours. According to Gajewski et al. (1999), the intravenous injection of oxytocin and carbetocin always caused strong uterine contractions, and changes in uterine activity were commonly associated with plasma P4 and estrogen levels.

\section{Conclusion}

The resumption of ovarian activity in the postpartum period constitutes a fundamental factor of good reproductive performance in dairy cattle. Ovarian activity induces optimal uterine involution and the postpartum restoration of endocrine function, which results in the desired reduction in the reproductive waiting period. As well, the knowledge and tracking of physiological ovarian follicular dynamics provides the veterinarian with the necessary information to take preventative action and to treat disorders that could cause significant losses. Finally, ultrasonography has proven to be a promising tool with relevant applicability to improved reproductive efficiency on modern cattle farms.

\section{References}

Adams GP. Comparative patterns of follicle development and selection in ruminants. Journal of Reproduction and Fertility. 1999; 54:17-32.

Adams GP, Jaiswal R, Singh J, Malhi P. Progress in understanding ovarian follicular dynamics in cattle. Theriogenology. 2008; 69(1):72-80.

Adams GP, Pierson RA. Bovine model for study of ovarian follicular dynamics in humans. Theriogenology. 1995; 43(1):113-120. doi:10.1016/0093-691X(94)00015-M.

Adams GP, Singh J, Baerwald AR. Large animal models for the study of ovarian follicular dynamics in women. Theriogenology. 2012; 78(8):1733-1748. doi:10.1016/j.theriogenology.2012.04.010.

Aerts JM, Bols PE. Ovarian follicular dynamics: a review with emphasis on the bovine species. Part I: Folliculogenesis and pre-antral follicle development. Reproduction in Domestic Animals. 2010; 45(1):171179. doi: 10.1111/j.1439-0531.2008.01302.x.

Aguilar DJ, Santos RR, Garcia-Muniz JG. Effect of milk yield, number of calving and calving season on the resumption of postpartum ovarian activity in Holstein cows. Revista Científica Facultad Ciencias Veterinarias. 2004; 14(6):548-558.

Amer HA. Ultrasonographic assessment of early pregnancy diagnosis, fetometry and sex determination in goats. Animal Reproduction Science. 2010; 117(34):226-231. doi:10.1016/j.anireprosci.2009.05.015.

Artunduaga MAT, Sá Fortes RV, Coelho SG, Reis RB, Lana AMQ, Carvalho AU, Marques Júnior AP. Ovarian activity of dairy cows receiving diets with propylene glycol or monensin during the transition period. Arquivo Brasileiro de Medicina Veterinária e Zootecnia. 2008; 60(2):289-293. doi:10.1590/ S0102-09352008000200002. 
Azawi OI. Postpartum uterine infection in cattle. Animal Reproduction Science. 2008; 105(3-4):187208. doi:10.1016/j.anireprosci.2008.01.010.

Bajcsy AC, Szenci O, Doornenbal A, van der Weyden GC, Csorba C, Kocsis L, Szucs I, Ostgard S, Taverne MA. Characteristics of bovine early puerperal uterine contractility recorded under farm conditions. Theriogenology. 2005; 64(1):99-111. doi:10.1016/j. theriogenology.2004.11.005.

Barboni B, Turriani M, Galeati G, Spinaci G, Bacci ML, Forni M, Mattiolo M. Vascular endothelial growth factor production in growing pig antral follicles, Biology of Reproduction. 2000; 63(3):858-864.

Bergfelt DR, Lightfoot KC, Adams GP. Ovarian dynamics following ultrasound-guided transvaginal follicle ablation in cyclic heifers. Theriogenology. 1994; 41(1):161-168.doi:10.1016/S0093-691X(05)80071-8.

Bertoni G, Trevisi E, Han X, Bionaz M. Effects of inflammatory conditions on liver activity in puerperium period and consequences for performance in dairy cows. Journal of Dairy Science. 2008; 91(9):3300-3310.

Bó GA, Adams GP, Mapletoft RJ. Follicular dynamics in cattle. In: Simpósio sobre controle estral em ruminantes, 2000, São Paulo. Anais... São Paulo: Universidade de São Paulo, 2000. p. 12-34.

Bó GA, Baruselli PS, Martínez MF. Pattern and manipulation of follicular development in Bos indicus cattle. Animal Reproduction Science. 2003; 78(34):307-326. doi:10.1016/S0378-4320(03)00097-6.

Borges AM, Torres CAA, Ruas JRM, Rocha Júnior VR, Carvalho GR. Ovarian follicular dynamics in crossbreed Holstein-Zebu heifers. Arquivo Brasileiro de Medicina Veterinária e Zootecnia. 2001; 53(5):595-604. doi:10.1590/S0102-09352001000500015.

Butler WR. Nutritional interactions with reproductive performance in dairy cattle. Animal Reproduction Science. 2000; 60-61:449-457. doi:10.1016/ S0378-4320(00)00076-2.

Butler WR, Smith RD. Interrelationships between energy balance and postpartum reproductive function in dairy cattle. Journal of Dairy Science. 1989; 72(3):767-783, 1989. doi:10.3168/jds.S0022-0302(89)79169-4.
Carvalho CF. Bases físicas da formação da imagem ultrassonográfica, In: Carvalho CF. Ultrassonografia em pequenos animais. 1 ed. São Paulo: Roca; 2004. p. 1-7.

Casasola AQ, Reyes LA, Cruz UM, Godínez JAR, Calderón AC. Estrus behavior, ovarian dynamics and progesterone secretion in Criollo cattle during estrous cycles with two and three follicular waves. Tropical Animal Health and Production. 2014; 46(4):675-684. doi:10.1007/ s11250-014-0562-0.

Castaneda-Gutierrez E, Pelton SH, Gilbert RO, Butler WR. Effect of peripartum dietary energy supplementation of dairy cows on metabolites, liver function and reproductive variables. Animal Reproduction Science. 2009; 112(34):301-315. doi:10.1016/j.anireprosci.2008.04.028.

Cerri RLA, Chebel RC, Rivera F, Narciso CD, Oliveira RA, Amstalden M, Baez-Sandoval GM, Oliveira LJ, Thatcher WW, Santos JE. Concentration of progesterone during the development of the ovulatory follicle: II. Ovarian and uterine responses. Journal of Dairy Science. 2011; 94(7):3352-3365. doi:10.3168/jds.2010-3735.

Chase CCJr, Kirby CJ, Hammond AC, Olson TA, Lucy MA. Patterns of ovarian growth and development in cattle with a growth hormone receptor deficiency. Journal of Animal Science. 1998; 76(1):212-219.

Chasombat J, Nagai T, Parnpai R, Vongpralub T. Ovarian follicular dynamics, ovarian follicular growth, oocyte yield, in vitro embryo production and repeated oocyte pick up in Thai native heifers undergoing superstimulation. Asian-Australasian Journal of Animal Science. 2013; 26(4):488-500. doi:10.5713/ajas.2012.12519.

Cummins SB, Lonergan P, Evans AC, Butler ST. Genetic merit for fertility traits in Holstein cows: II. Ovarian follicular and corpus luteum dynamics, reproductive hormones, and estrus behavior. Journal of Dairy Science. 2012; 95(7):3698-3710. doi:10.3168/jds.2011-4976.

D’enjoy D, Cabrera P, Vivas I, Díaz T. Ovarian follicular dynamics during estrous cycle in Brahman cows. Revista de la Facultad Ciencias Veterinarias UCV. 2012; 53(1):39-47.

de la Sota RL, Simmen FA, Diaz T, Thatcher WW. Insulinlike growth factor system in bovine first-wave dominant and subordinate follicles. Biology of Reproduction. 1996; 55(4):803-812. 
Domínguez MM. Effects of body condition, reproductive status and breed on follicular population and oocyte quality in cows. Theriogenology. 1995; 43(8):1405-1418. doi:10.1016/0093-691X(95)00126-S.

Driancourt MA. Regulation of ovarian follicular dynamics in farm animals: Implications for manipulation of reproduction. Theriogenology. 2001; 55(6):1211-1239. doi:10.1016/S0093-691X(01)00479-4.

Drost WT. Física básica do ultrassom. In: Thrall DE. Diagnóstico de radiologia veterinária. 5 ed. Rio de Janeiro: Elsevier; 2010. p. 38-49.

Duffy P, Crowe MA, Boland MP, Roche JF. Effect of exogenous LH pulses on the fate of the first dominant follicle in postpartum beef cows nursing calves. Journal of Reproduction and Fertility. 2000; 118(1):9-17.

Elkjær K, Ancker ML, Gustafsson H, Friggens NC, Waldman A, Mølback L, Callesen H. Uterine bacterial flora in postpartum Danish Holstein dairy cows determined using DNA-based fingerprinting: Correlation to uterine condition and calving management. Animal Reproduction Science. 2013; 138(1-2):39-48. doi:10.1016/j. anireprosci.2013.01.016.

Esposito G, Irons PC, Webb EC, Chapwanya A. Interaction between negative energy balance, metabolic diseases, uterine health and immune response in transition dairy cows. Animal Reproduction Science. 2014; 144(3-4):6071. doi:10.1016/j.anireprosci.2013.11.007.

Evans AC, Adams GP, Rawlings NC. Follicular and hormonal development in prepubertal heifers from 2 to 36 weeks of age. Journal of Reproduction and Fertility. 1994; 102(2):463-470.

Fatima LA, Evangelista MC, Silva RS, Cardoso APM, Baruselli PS, Papa PC. FSH up-regulates angiogenic factors in luteal cells of buffaloes. Domestic Animal Endocrinology. 2013; 45(4):224-237. doi:10.1016/j. domaniend.2013.09.004.

Ferguson JD. Nutrition and reproduction in dairy cows. The Veterinary Clinics of North America. Food Animal Practice. 1991; 7(2):483-507.

Figueiredo RA. Prevalence of two waves of ovarian follicular growth in Nelore cows. Revista Brasileira de Reprodução Animal. 1995; 19:200-211.
Figueiredo RA, Barros CM, Pinheiro OL, Soler JM. Ovarian follicular dynamics in Nelore breed (Bos indicus) cattle. Theriogenology. 1997; 47(8):1489-1505.

FoldiJ, Kulcsár M, Pécsi A, HuygheB, deSAC, LohuisJACM, Cox P, Huszenicza G. Bacterial complications of postpartum uterine involution in cattle. Animal Reproduction Science. 2006; 96(3-4):265-281. doi:10.1016/j.anireprosci.2006.08.006.

Fortune JE, Yang MY, Allen JJ, Herrick SL. Triennial Reproduction Symposium: the ovarian follicular reserve in cattle: what regulates its formation and size?. Journal of Animal Science. 2013; 91(7):3041-3050. doi: 10.2527/ jas.2013-6233.

Fortune JE. Follicular dynamics during the bovine estrous cycle: A limiting factor in improvement of fertility? Animal Reproduction Science. 1993; 33(1-4):111-125. doi:10.1016/0378-4320(93)90110-D.

Gabler C, Drillich M, Fischer C, Holder C, Heuwieser W, Einspanier R. Endometrial expression of selected transcripts involved in prostaglandin synthesis in cows with endometritis. Theriogenology. 2009; 71(6):993-1004. doi: 10.1016/j.theriogenology.2008.11.009.

Gajewski Z, Thun R, Faundez R, Boryczko A. Uterine motility in the cow during puerperium. Reproduction in Domestic Animals. 1999; 34(3-4):185-191. doi:10.1111/j.1439-0531.1999.tb01239.x.

Gambini ALG, Moreira MBP, Castilho C, Barros CM. Desenvolvimento folicular e sincronização da ovulação em vacas da raça Gir. Revista Brasileira de Reprodução Animal. 1998; 22(4):201-210.

Gibbons JR, Wiltbank MC, Ginther OJ. Functional interrelationships between follicles greater than $4 \mathrm{~mm}$ and the FSH surge in heifers. Biology of Reproduction. 1997; 57(5):1066-1073.

Ginther OJ, Pierson RA. Ultrasonic anatomy of equine ovaries. Theriogenology. 1984; 21(3):471-483.

Ginther OJ, Wiltbank MC, Fricke PM, Gibbons JR, Kot K. Selection of the dominant follicle in cattle. Biology of Reproduction. 1996; 55(6):1187-1194.

Grunert E, Birgel EH. Obstetrícia veterinária. Porto Alegre: Sulina; 1998.

Hafez ESE. Reprodução Animal. 6 ed. São Paulo: Manole; 1995. 
Heppelmann M, Weinert M, Brommling A, Piechotta M, Hoedemaker M, Bollwein $H$. The effect of puerperal uterine disease on uterine involution in cows assessed by Doppler sonography of uterine arteries. Animal Reproduction Science. 2013; 143(1-4):1-7. doi:10.1016/j. anireprosci.2013.11.003.

Herzog K, Bollwein H. Application of Doppler Ultrassonography in cattle reproduction. Reproduction in Domestic Animals. 2007; 42(S2):51-58. doi:10.1111/j.1439-0531.2007.00903.x.

Ireland JJ, Mihm M, Austin E, Diskin MG, Roche JF. Historical perspective of turnover of dominant follicles during the bovine estrous cycle: key concepts, studies, advancements and terms. Journal of Dairy Science. 2000; 83(7):1648-1658.

Ireland JJ, Roche JF. Development of nonovulatory antral follicles in heifers: changes in steroids on follicular fluid and receptors for gonadotropins. Endocrinology. 1983; 112(1):150-156.

Jaiswal RS. Regulation of follicular wave patterns in cattle. 2007. 185 p. PhD thesis (Doctorate of Philosophy) Department of Veterinary Biomedical Sciences, University of Saskatchewan, Canada, 2007.

Kealy JK, MCallister HA. Radiografia, radiologia e ultrassonografia do cão e do gato. 3 ed. São Paulo: Manole; 2005. p. 7-18.

Kendrick KW, Bailey TL, Garst AS, Pryor AW, Ahmadzadeh A, Akers RM, Eyestone WE, Pearson RE, Gwazdauskas FC. Effects of energy balance on hormones, ovarian activity, and recovered oocytes in lactating Holstein cows using transvaginal follicular aspiration. Journal of Dairy Science. 1999; 82(8):1731-1749. doi:10.3168/jds. S0022-0302(99)75403-2.

Ko JCH, Kastelic JP, Del Campo MR, Ginther OJ. Effects of a dominant follicle on ovarian follicular dynamics during the oestrous cycle in heifers. Journal of Reproduction and Fertility. 1991; 91(2):511-519. doi:10.1530/ jrf.0.0910511.

Kornmatitsuk S, Kornmatitsuk B, Chantaraprateep P, Larsson B. Characteristics of oestrous cycles in Holstein cross-breed dairy heifers: An evidence of delayed postovulatory progesterone rise. Tropic Animal Health and Production. 2009; 41(3):337-344. doi:10.1007/ s11250-008-9194-6.
Kozicki LE. Uber den postpartalen Zyklusverlaufbei Kuhen unter verschiedenen Haltungsbedingungen, dargestellt anhand von klinischen Erhebungen und von Progesteronbestimmungen in Milchproben mit Hilfe des Enzymimmuntests und Radioimmuntests. 1982. $186 \mathrm{f}$. Thesis (Doktor Veterinarmedizin) - Justus Liebig universitat Giessen, Germany, 1982.d

Krause ART, Pfeifer LFM, Montagner P, Weschenfelder MM, Schwegler E, Lima ME, Xavier EG, Brauner CC, Schimitt E, Del Pino FAB, Martins CF, Corrêa MN, Schneider A. Association between resumption of postpartum ovarian activity, uterine health and concentrations of metabolites and acute phase proteins during the ransition period in Holstein cows. Animal Reproduction Science. 2014; 145(1-2):8-14. doi:10.1016/j.anireprosci.2013.12.016.

Kremkau FW. Diagnostic ultrasound: principles and instruments. Philadelphia: W. B. Saunders Co., 1998.

Laven RA, Dawuda PM, Scaramuzzi RJ, Wathes DC, Biggadike HJ, Peters AR. The effect of feeding diets high in quickly degradable nitrogen on follicular development and embryo growth in lactating Holstein dairy cows. Animal Reproduction Science. 2004; 84(1-2):41-52.

Leroy JL, Vanholder T, Van Knegsel AT, Garcia-Ispierto I, Bols PE. Nutrient prioritization in dairy cows early postpartum:mismatchbetweenmetabolismandfertility?. Reproduction in Domestic Animals. 2008; 43(S2):96103. doi:10.1111/j.1439-0531.2008.01148.x.

Lopez H, Caraviello DZ, Satter LD, Fricke PM, Wiltbank MC. Relationship between level of milk production and multiple ovulation in lactating dairy cows. Journal of Dairy Science. 2005; 88(8):2783-2793. doi:10.3168/ jds.S0022-0302(05)72958-1.

Lucy MC. Regulation of ovarian follicular growth by somatotropin and insulin-like growth factors in cattle. Journal of Dairy Science. 2000; 83(7):1635-1647. doi:10.3168/jds.S0022-0302(00)75032-6.

Mateus L, Costa LL, Diniz P, Ziecik AJ. Relationship between andotoxin and prostaglandin (PGE2 and PGFM) concentrations and ovarian function in dairy cows with puerperal endometritis. Animal Reproduction Science. 2003; 76(3-4):143-154. doi:10.1016/ S0378-4320(02)00248-8. 
Mateus L, Costa LL, Bernardo F, Silva JR. Influence of puerperal uterine infection on uterine involution and postpartum ovarian activity in dairy cow. Reproduction in Domestic Animals. 2002; 37(1):31-35. doi:10.1046/j.1439-0531.2002.00317.x.

Mazerbourg S, Zapf J, Bar RS, Brigstock DR, Lalou C, Binoux $\mathrm{M}$, Monget $\mathrm{P}$. Insulin like growth factor binding protein-4 protelytic degradation in ovine preovulatory follicle: studies of underlying mechanisms. Endocrinology. 1999; 140(9):4175-4184.

Macmillan KL, Thatcher WW. Effects of and agonist of gonadotropin-releasing hormone on ovarian follicles in cattle. Biology of Reproduction. 1991; 45(6):883-889.

Medan SM, Abd El-Aty AM. Advances in ultrasonography and its applications in domestic ruminants and other farm animals reproduction. Journal of Advances Research. 2010; 1(2):123-128. doi:10.1016/j.jare.2010.03.003.

Mihm M, Good TE, Ireland JL, Ireland JJ, Knight PG, Roche JF. Decline in serum FSH alters key intrafollicular growth factors involved in selection of the dominant follicle in heifers. Biology of Reproduction. 1997; 57(6):1328-1337. doi:10.1095/biolreprod57.6.1328.

Murphy MG, Enright WJ, Crowe MA, McConnel K, Spicer LJ, Boland MP, Roche JF. Effect of dietary intake on pattern of growth of dominant follicles during the oestrous cycle in beef heifers. Journal of Reproduction and Fertility. 1991; 92(2):333-338.

Nepomuceno AC, Canola IC, Oliveira MEF, Avante ML. Princípios físicos da ultrassonografia e aplicações na reprodução animal. In: Feliciano MAR, Oliveira MEF, Vicente WRR. Ultrassonografia na Reprodução Animal. 1 ed. São Paulo: Editora Medvet; 2013. p. 1-16.

Oliveira Filho BD, Toniollo GH, Oliveira AFD, Viu MAO, Ferraz HT, Lopes DT, Gambarini ML. The effect of offering energy and protein supplement to grazing canchim beef cows either postpartum or both pre-and postpartum on lipid blood metabolites and folliculogenesis. Animal Reproduction Science. 2010; 121(1-2):39-45. doi:10.1016/j.anireprosci.2010.04.192.

Opsomer G, Coryn M, Deluyker H, Kruif A. An analysis of ovarian dysfunction in high yielding dairy cows after calving based on progesterone profiles. Reproduction Domestic Animals. 1998; 33(3-4):193-204. doi:10.1111/j.1439-0531.1998.tb01342.x.
Opsomer G, Grohn YT, Hertl J, Coryn M, Deluyker H, Kruel A. Risk factors for post partum ovarian dysfunction in high producing dairy cows in Belgium: a field study. Theriogenology. 2000; 53(4):841-857. doi:10.1016/ S0093-691X(00)00234-X.

Peixoto GCX, Lira RA, Alves ND, Silva AR. Bases físicas da formação da imagem ultrassonográfica. Acta Veterinaria Brasílica. 2010; 4(1):15-24.

Peter AT. An update on cystic ovarian degeneration in cattle. Reproduction in Domestic Animals. 2004; 39(1):1-7.

Peter AT, Vos PLAM, Ambrose DJ. Postpartum anestrus in dairy cattle. Theriogenology. 2009; 71(9):1333-1342. doi:10.1016/j.theriogenology.2008.11.012.

Peter AT, Bosu WT. Relationship of uterine infections and folliculogenesis in dairy cows during early puerperium. Theriogenology. 1988; 30(6):1045-1051.

Peter AT, Bosu WT, Gilbert RO. Absorption of Escherichia coli endotoxin (lipopolysaccharide) from the uteri of postpartum dairy cows. Theriogenology. 1990; 33(5):1011-1014.

Petersson KJ, Gustafsson H, Strandberg E, Berglund B. Atypical progesterone profiles and fertility in Swedish dairy cows. Journal of Dairy Science. 2006; 89(7):25292538. doi:10.3168/jds.S0022-0302(06)72328-1.

Pierson RA, Adams GP. Computer-assisted image analysis, diagnostic ultrasonography and ovulation induction: strange bedfellows. Theriogenology. 1995; 43(1):105112. doi:10.1016/0093-691X(94)00014-L.

Pretheeban T, Balendran A, Gordon MB, Rajamahendran R. mRNA of luteal genes associated with progesterone synthesis, maintenance, and apoptosis in dairy heifers and lactating dairy cows. Animal Reproduction Science. 2010; 121(3-4):218-224. doi:10.1016/j. anireprosci.2010.05.016.

Rajakoski E. The ovarian follicular system in sexually mature heifers with special reference to seasonal, cyclical, and left-right variations. Acta Endocrinologica. 1960; 34(S3):7-68. doi:10.1530/acta.0.XXXIVS0007.

ROCHE, J.F. The effect of nutritional management of the dairy cow on reproductive efficiency. Animal Reproduction Science. 2006; 96(3-4):282-296. doi:10.1016/j.anireprosci.2006.08.007. 
Sá Filho MS, Marques MO, Gimenes LU, Torres-Júnior JRS, Batista EOS, Carvalho JPB, Baruselli PS. Prostaglandin treatment at the onset of norgestomet and estradiolbased synchronization protocols dis not alter the ovarian follicular dynamics or pregnancy per timed artificial insemination in cyclic Bos indicus heifers. Animal Reproduction Science. 2014; 144(1-2):1-5. doi:10.1016/j. anireprosci.2013.11.008.

Salamone DF, Adams GP, Mapletoft RJ. Changes in the cumulus-oocyte complex of subordinate follicles relative to follicular wave status in cattle. Theriogenology. 1999; 52(4):549-561.

Sales JN, Carvalho JB, Crepaldi GA, Cipriano RS, Jacomini JO, Maio JR, Souza JC, Nogueira GP, Baruselli PS. Effects of two estradiol esters (benzoate and cypionate) on the induction of synchronized ovulation in Bos indicus cows submitted to a timed artificial insemination protocol. Theriogenology. 2012; 78(3):510-516. doi:10.1016/j. theriogenology.2012.02.031.

Sangsritavong S, Combs DK, Sartori R, Armentano LE, Wiltbank MC. High feed intake increases liver blood flow and metabolism of progesterone and estradiol-17 $\beta$ in dairy cattle. Journal of Dairy Science. 2002; 85(11):2831-2842. doi:10.3168/jds.S0022-0302(02)74370-1.

Santos RM, Vasconcelos JLM. Effect of the interval of follicular recruitments on superovulatory response in nonlactanting Holstein cows. Arquivo Brasileiro de Medicina Veterinária eZootecnia. 2007; 59(4):844-850. doi:10.1590/ S0102-09352007000400004.

Sartori R, Haughian JM, Shaver RD, Rosa GJM, Wiltbank MC. Comparison of ovarian function and circulating steroids in estrous cycles of Holstein heifers and lactating cows. Journal of Dairy Science. 2004; 87(4):905-920. doi:10.3168/jds. S0022-0302(04)73235-X;

Sartori R, Mollo MR. Influência da ingestão alimentar na fisiologia reprodutiva da fêmea bovina. Revista Brasileira de Reprodução Animal. 2007; 31(2):197-204.

Satchel L, Glister C, Bleach EC, Glencross RG, Bicknell AB, Dai Y, Anand-Ivell R, Ivell R, Knight PG. Ovarian expression of insulin-like peptide 3 (INSL3) and its receptor (RXFP2) during development of bovine antral follicles and corpora lutea and measurement of circulating INSL3 levels during synchronizes estrous cycles. Endocrinology. 2013; 154(5):1897-1906. doi:10.1210/en.2012-2232.
Schneider A, SchimittE, Schwegler E, Ferterseifer SR, Rabassa VRA. A integração metabólica determinando a ocorrência de transtornos clínico-metabólicos mistos. In: Gonzalez FHD, Silva SC, Correa MN. Transtornos metabólicos nos animais domésticos. Porto Alegre: UFRGS; 2014. p. 291-304.

Sheldon IM, Dobson H. Postpartum uterine health in cattle. Animal Reproduction Science. 2004; 82-83:295-306. doi:10.1016/j.anireprosci.2004.04.006.

Sheldon IM, Noakes DR, Rycroft AN, Dobson H. Effect of postpartum manual examination of the vagina on uterine bacterial contamination in cows. The Veterinary Record. 2002a; 151(18):531-534.

Sheldon IM, Noakes DE, Rycroft AN, Pfeifer DU, Dobson $\mathrm{H}$. Influence of uterine bacterial contamination after parturition on ovarian dominance follicle selection under follicle growth and function in cattle. Reproduction. 2002b; 123(6):837-845.

Sheldon IM. The postpartum uterus. Veterinary Clinics: Food Animal Practice. 2004; 20(3):569-591. doi:10.1016/j. cvfa.2004.06.008.

Skarzynski DJ, Piotrowska-Tomala KK, Lukasik K, Galvão A, Farberov S, Zalman Y, Meidan R. Growth and regression in bovine corpora lutea: regulation by local survival and death pathways. Reproduction in Domestic Animals. 2013; 48(S1):25-37. doi:10.1111/rda.12203.

Silvestre FT, Bartolome JA, Kamimura S, Arteche AC, Pancarci SM, Trigg T, Thatcher WW. Postpartum suppression of ovarian activity with a Deslorelin implant enhanced uterine involution in lactating dairy cows. Animal Reproduction Science. 2009; 110(1-2):79-95. doi:10.1016/j. anireprosci.2007.12.015

Silvestre FT, Carvalho TSM, Crowford PC, Santos JEP, Staples CR, Jenkins T, Thatcher WW. Effects of differential supplementation of fatty acids during the peripartum and breeding periods of Holstein cows: II. Neutrophil fatty acids and function and acute phase proteins. Journal of Dairy Science. 2011; 94(5):2285-2301. doi:10.3168/ jds.2010-3371.

Simões RAL, Satrapa RA, Rosa FS, Piagentini M, Castilho ACS, Ereno RL, Trinca LA, Nogueira MFG, Buratini Jr J, Barros CM. Ovulation rate and its relationship with follicle diameter and gene expression of the LH receptor (LHR) in Nelore cows. Theriogenology. 2012; 77(1):139147. doi:10.1016/j.theriogenology.2011.07.027. 
Singh J, Adams GP. Immunohistochemical distribution of follistatin in dominant and subordinate follicles and the corpus luteum of cattle. Biology of Reproduction. 1998; 59(3):561-570.

Singh J, Adams GP, Pierson RA. Promise of new imaging technologies for assessing ovarian function. Animal Reproduction Science. 2003; 78(3-4):371-399.

Singh J, Pierson RA, Adams GP. Ultrasound image attributes of bovine ovarian follicles and endocrine and functional correlates. Journal of Reproduction and Fertility. 1998; 112(1):19-29.

Singh J, Pierson RA, Adams GP. Ultrasound image attributes of the bovine corpus luteum: structural and functional correlates. Journal of Reproduction and Fertility. 1997; 109(1):35-44.

Singh J, Adams GP. Histomorphometry of dominant and subordinate bovine ovarian follicles. The Anatomical Record. 2000; 258(1):58-70.

Singh J, Brogliattil GM, Christensen CR, Adams GP. Active immunization against follistatin and its effect on FSH, follicle development and superovulation in heifers. Theriogenology. 1999; 52(1):49-66.

Sirois J, Fortune JE. Lengthening the bovine estrous cycle with low levels of exogenous progesterone: a model for studying ovarian follicular dominance. Endocrinology. 1990; 127(2):916-925.

Stubbs SA, Weber LJ, Stark J, Rice S, Margara R, Lavery S, Trew GH, Hardy K, Franks S. Role of insulins-like growth factors in initiation of follicle growth in normal and polycystic human ovaries. The Journal of Clinical Endocrinology and Metabolism. 2013; 98(8):32983305. doi:10.1210/jc.2013-1378.

Tabatabaei S, Mamoei M, Aghaei A. Dynamics of ovarian follicular fluid in cattle. Comparative Clinical Pathology. 2011; 20(6):591-595. doi:10.1007/ s00580-010-1038-x.

Takedomi T, Kishi H, Medan MS, Aoyagi Y, Konishi A, Itoh T, Yazawa A, Watanabe G, Taya K. Active immunization against inhibin improves superovulatory response to exogenous FSH in cattle. Journal of Reproduction and Development. 2005; 51(3):341-346. doi:10.1262/ jrd.16055.
Tamminga S. The effect of the supply of rumen degradable protein and metabolisable protein on negative energy balance and fertility in dairy cows. Animal Reproduction Science. 2006; 96(3-4):227239. doi:10.1016/j.anireprosci.2006.08.003.

Thatcher WW, Bilby TR, Bartolome JA, Silvestre F, Staples CR, Santos JEP. Strategies for improving fertility in the modern dairy cow. Theriogenology. 2006; 65(1):30-44. doi:10.1016/j. theriogenology.2005.10.004.

Thatcher WW, Wilcox CJ. Postpartum estrus as an indicator of reproductive status in the dairy cow. Journal of Dairy Science. 1973; 56(5):608-610. doi:10.3168/jds.S0022-0302(73)85227-0.

Tom JW, Pierson RA, Adams GP. Quantitative echotexture analysis of bovine corpora lutea. Theriogenology. 1998; 49(7):1345-1352.

Turk R, Juretic D, Geres D, Svetina A, Turk N, Flegar-Mestric Z. Influence of oxidative stress and metabolic adaptation on PON1 activity and MDA level in transition dairy cows. Animal Reproduction Science. 2008; 108(1-2):98-106. doi:10.1016/j. anireprosci.2007.07.012.

Uslenghi G, Chaves SG, Cabodevila J, Callejas S. Effect of estradiol cypionate and amount of progesterone in the intravaginal device on synchronization of estrus, ovulation and pregnancy rate in beef cows treated with FTAI based protocols. Animal Reproduction Science. 2014; 145(1-2):1-7. doi:10.1016/j. anireprosci.2013.12.009.

Utt MD, Jousan FD, Beal WE. The effects of varying the interval from follicular wave emergence to progestin withdrawal on follicular dynamics and the synchrony of estrus in beef cattle. Journal of Animal Science. 2003; 81(6):1562-1567.

Vasconcelos JLM. Control of estrus and ovulation in order to artificially fixed time insemination in dairy cattle. In: Simpósio sobre controle farmacológico do ciclo estral em ruminantes, 2000, São Paulo. Anais... São Paulo: Universidade de São Paulo; 2000. p. 115-157.

Vassena R. Bovine oocyte competence. 2001. Thesis (MSc. Degree) - University of Saskatchewan, Saskatoon, Canada, 2001. 
Vassena R, Adams GP, Mapletoft RJ, Pierson RA, Singh J. Ultrasound image characteristics of ovarian follicles in relation to oocyte competence and follicular status in cattle. Animal Reproduction Science. 2003; 76(1-2):2541. doi:10.1016/S0378-4320(02)00234-8.

Viana JH, Palhao MP, Siqueira LG, Fonseca JF, Camargo LS. Ovarian follicular dynamics, follicle deviation and oocyte yield in Gyr breed (Bos indicus) cows undergoing repeated ovum pick-up. Theriogenology. 2010; 73(7):966-972.

Villa-Godoy A, Hughes TL, Emery RS, Chapin LT, Fogwell RL. Association between energy balance and luteal function in lactating dairy cows. Journal of Dairy Science. 1988; 71(4):1063-1072. doi:10.3168/jds. S0022-0302(88)79653-8.

Walsh RB, Kelton DF, Duffield TF, Leslie KE, Walton JS, Leblanc SJ. Prevalence and risk factors for postpartum anovulatory condition in dairy cows. Journal of Dairy Science. 2007; 90(1):315-324.

Williams EJ, Fischer DP, Noakes DE, England GCW, Rycroft A, Dobson H, Sheldon IM. The relationship between uterine pathogen growth density and ovarian function in the postpartum dairy cows. Theriogenology. 2007; 68(4):549559. doi:10.1016/j.theriogenology.2007.04.056.

Zain AE, Nakao T, Raouf MA, Moriyoshi M, Kawata K, Moritsu Y. Factors in the resumption of ovarian activity and uterine involution in postpartum dairy cows. Animal Reproduction Science. 1995; 38(3):203-214. doi:10.1016/0378-4320(94)01359-T.
Zeitoun MM, Rodriguez HF, Randel RD. Effect of season on ovarian follicular dynamics in Brahman cows. Theriogenology. 1996; 45(8):1577-1581. doi:10.1016/0093-691X(96)00126-4.

Zeleznik AJ, Schuler HM, Reichert Jr LE. Gonadotropinbinding sites in the rhesus monkey ovary: role of the vasculature in the selective distribution of human chorionic gonadotropin to the preovulatory follicle. Endocrinology. 1981; 109(2):356-362.

Zulu VC, Sawamukai Y, Nakada K, Kida K, Moriyoshi M. Relationship among insulin-like growth factor-I, blood metabolites and postpartum ovarian function in dairy cows. The Journal of Veterinary Medical Science. 2002; 64(10):879-885.

Zurek E, Foxcroft GR, Kennelly JJ. Metabolic status and interval to first ovulation in postpartum cows. Journal of Dairy Science. 1995; 78(9):1909-1920. doi:10.3168/ jds.S0022-0302(95)76816-3

Recebido em: 14/07/2015 Received in: 07/14/2015

Aprovado em: 24/09/2015 Approved in: 09/24/2015 